\title{
ROLE AND IMPORTANCE OF MINING CITIES IN THE ECONOMIC DEVELOPMENT OF THE REGION (S)
}

\section{Isabek B. Murtazaev}

Department of Economics

National University of Uzbekistan named after Mirzo Ulugbek

100174, 4 University Street Str., Tashkent, Republic of Uzbekistan

isabekmurtazayev777@mail.ru

\section{ABSTRACT:}

This article examines different approaches to the concept of mono-cities, the criteria for defining monocities, the specific features and problems of their socio-economic development. Along with the development of industry, it is observed that the economy of some cities is dependent on a particular industry or the activities of any industrial enterprise, that is, monospecialization occurs. The crisis of this sector and two industrial enterprises causes many socio-economic and demographic problems. Therefore, in the era of industrialization, many approaches to the concept of mono-cities have been formed, and the study of mono-cities is becoming increasingly important. In this work, the essence of mono-cities and the features of their development were studied. The purpose of the article is to analyze the various approaches to the essence of the concept of monocity and to study the features of their socio-economic development, its task is to: analyze the definitions of the concept of monocity in foreign literature; study of factors influencing the formation and development of mono-cities; It is a study of the specialization and socio-economic problems of mono-cities of Uzbekistan.

Keywords:

Region, mono-city, resource cities, mining cities, industrial cities, mono-specialized areas, mono-structural, urban planning enterprise. economic system, unemployment, crisis, methodology, modernization, innovative development.

\section{Introduction}

It is known that the city is a densely populated area of population and nonagricultural sectors, the emergence of which is influenced by several factors, but one of them is the leading - the main factor. Cities are the mainstay of the economy of any country, and the economic and social stability of the country, the level of economic development depends directly on the system of cities in the region. Most of the industrial enterprises, which are an important branch of material production, most of which are in the service sector, banking and finance, science, culture centers, are usually concentrated in cities. Also, the fact that the bulk of enterprises producing various machines, mineral fertilizers and processing agricultural products are located in cities shows that they are also important in the development of the agro-economic sector.

The main part We often come across the terms of mono-city, mono-specialized city resource city, mining town, and we come across information related to them in various literatures. First of all, let's focus on the typologies related to the origin and functions of cities.

Genetic typology clearly shows when and on what basis cities came into being. Development of mineral deposits, the formation of a processing industry, recreation, science, management, etc. are among the main factors that shape the city. They will serve as a basis for the future development of cities. In some cases, the city may also develop under the influence of completely different factors in its subsequent development, which complicates the construction of the genetic typology.

If we look at the genetic typology of cities, the leading factors are based on the extraction of non-ferrous metal ores (Navoi, Uchkuduk, Zarafshan, Jezkazgan), processing industry (Cherepovets, Balkhashmed), shopping centers, markets (Tashkent, Dushanbe), military fortifications. appeared as (Otrar, Moscow). 
The function of a city is formed as a result of how it effectively uses the favorable opportunities of its geographical location. As the functions increase, the cities will grow and develop. In this respect, they are divided into single-function and multi-function cities. Determining the area in which cities specialize and the function they perform is done within the framework of functional typology. This will require the number of people employed in the urban economy. In relation to the total, the share of employment in the sector, which is the highest employment in the sector, the city will specialize in this area [1].

In terms of functional grouping, multifunctional capital cities (Tashkent), multifunctional regional centers (Andijan), multisectoral industrial cities (Chirchik), low-sectoral industrial cities (Zarafshan, Uchkuduk, Gazli), transport hubs (Kungrad), district centers (Khatirchi).), agroindustrial cities (Chelak, Besharik), recreation cities (Chartak, Nanay, Yangiabad), science centers (Ulugbek), etc. Mono-cities are settlements established in urban planning enterprises to provide production with labor resources. Typically, the term "mono-city" is applied to cities established in the territory of the former Soviet Union, as the organization of such settlements was the most common during this period [2].

It should be noted that most of the existing monotowns in the country were formed during this period. At present, there are more than 40 mono-specialized cities in the country, the main part of which is mining (Uchkuduk, Zarafshan, Muruntau, Gazgan, Ingichka, Marjanbulak, Koytash, Altynkon, Chorkesar, Chodak, etc.) and oil (Akshalak, Gazli), Karavulbozor, Mubarek, Shargun, Kakaydi, Lalmikor, Polvontash, etc.). In some of these cities, urban enterprises are still operating efficiently, while in others, due to the shortage of natural resources, obsolescence of technology, changes in market demand, excessive environmental problems, high dependence of city budgets on tax payments of urban enterprises, a number of socio-economic, demographic and environmental problems are occurring [3].

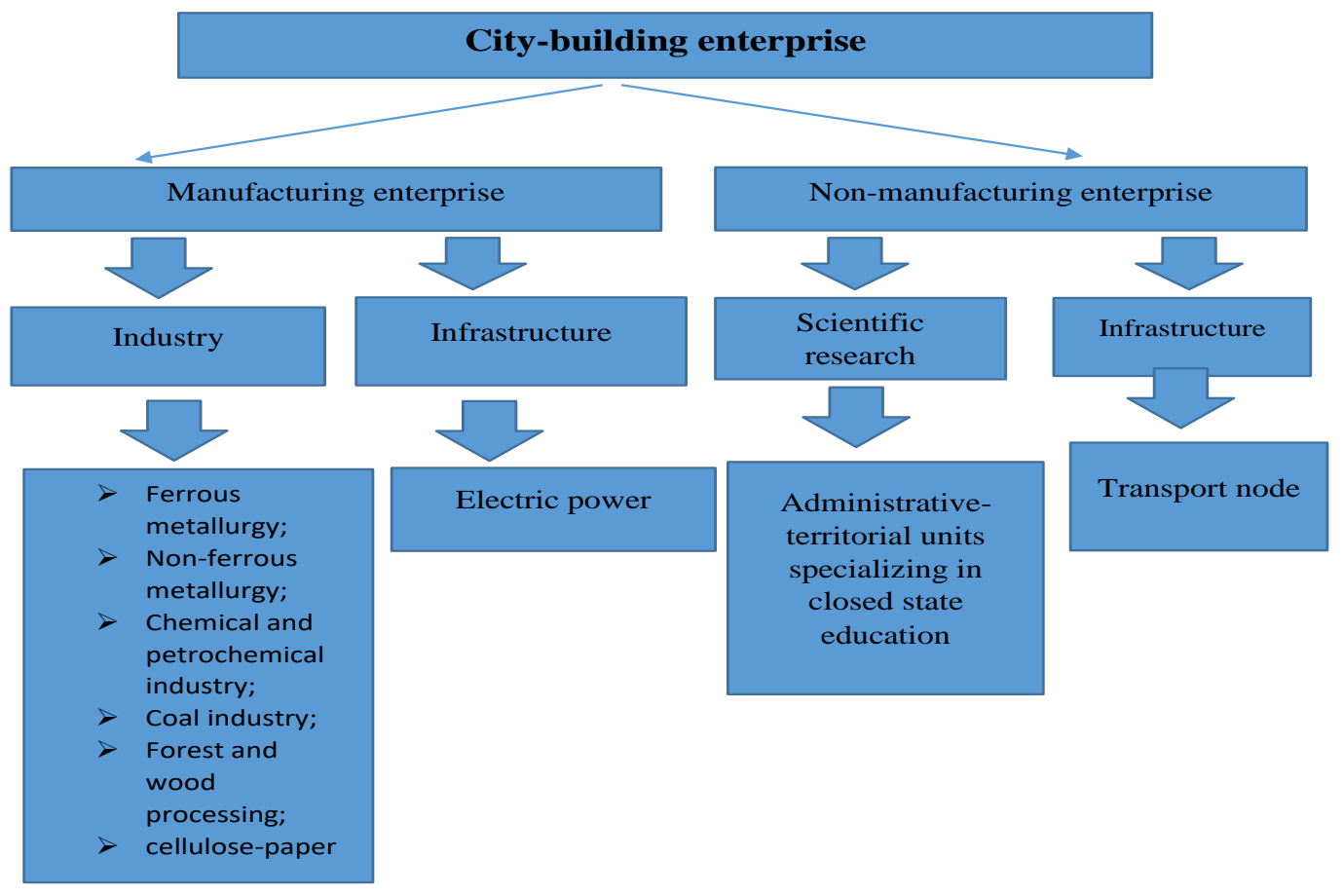

Figure 1. Intersectoral classification of city-forming enterprises 
The data show that in most cases, most of the enterprises that create mono-cities are organized with a focus on state defense or mineral and raw material orders. As a result, the socioeconomic situation in single-industry cities has evolved in response to political and economic changes in the state. ${ }^{1}$

Some researchers refer to the category of monofunctional cities created during the development of Siberia in the XI century and as a fortress city in the XV-XVI centuries. In this sense, settlements during the First Industrial Revolution can be linked to the single industries that began to emerge around the first metallurgical and mining cities in the Urals. In the 19th and 20th centuries, large areas of mono-cities were located in the Ruhr (Germany), central and southern Appalachia (USA), and central Scotland (UK), where they were mainly observed in the mining and metallurgical regions.

During this period, due to the sharp economic growth, the process of development of industries in the economy, often focused on specific national and international markets, was in full swing. In Central and Eastern Europe, monoorder settlements often appeared near long-term urban agglomerations. But during the twentieth century, the rate of creation of mono-cities in some Eastern European countries was much lower than in the former Soviet Union. For example, 24 settlements were established in Poland from 1950 to 1990 , and only 11 in Hungary ${ }^{2}$. In the 19th and 20th centuries, large areas of mono-cities were located in the Ruhr (Germany), central and southern Appalachia (USA), and central Scotland

\footnotetext{
1 Komilova, N.Kh., Hudayberganova, R.T, Murtazaev, I.B., Abdinazarova, H.O., \& Madaminov, Z.H. (2019). Economic and Geographic Problems of Improvement of Industrial Sectors and Local Structure of Uzbekistan. Journal of Advanced Research in Law and Economics, 10( 6 (44)), 1916-1928.

${ }^{2}$ Komilova, N. K., Haydarova, Ş. A., Xalmirzaev, A. A., Kurbanov, S. B., \& Rajabov, F. T. (2019). Territorial Structure of Agriculture Development in Uzbekistan in Terms of Economical Geography. Journal of Advanced Research in Law and Economics, 10(8 (46)), 2364-2372.
}

(UK), where they were mainly observed in the mining and metallurgical regions. During this period, due to the sharp economic growth, the process of development of industries in the economy, often focused on specific national and international markets, was in full swing [5].

In Central and Eastern Europe, mono-order settlements often appeared near long-term urban agglomerations. But during the twentieth century, the rate of creation of mono-cities in some Eastern European countries was much lower than in the former Soviet Union. For example, 24 settlements were established in Poland from 1950 to 1990, and only 11 in Hungary.

This feature of urban planning policy in the late 1920s was reinforced by the term 'urban shaping enterprise' [Figure 1].

Such mono-cities have been formed near natural resources, transport centers and major cities, on the territory of power plants, processing enterprises and in places where historical settlements are united. It should be noted that 3 types differ according to the formation and development of mono-specialized complexes. They are: agglomeration, raw materials, industrial cities (Figure 2).

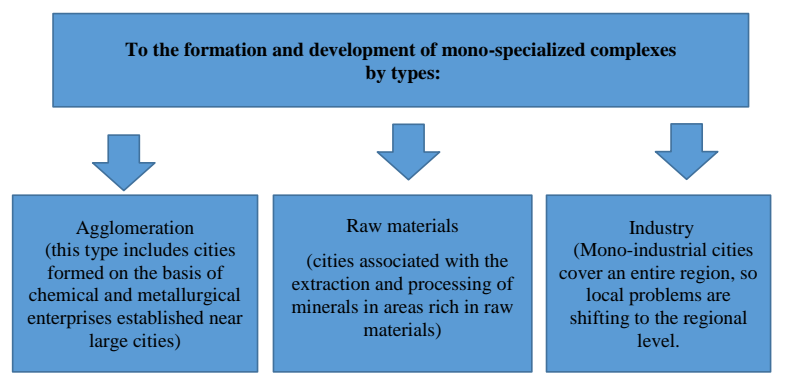

Figure 2. Classification of monocities

In the 1960s, at the initiative of $\mathrm{N}$. Khrushchev, a new wave of industry began, which formed an economy that extracted special resources and intensified the construction of new mono-cities in the machine-building, forest and wood processing, oil and gas industries. The new era was characterized by the same principles: construction in remote, desert areas, the connection of the city-manufacturing enterprise with others in a single production chain, the 
dependence of the city on the city-forming factory. The distinctive features of this period were nuclear and space programs, which resulted in the emergence of a new type of mono-order settlements in the former Soviet Union. ${ }^{3}$

In addition, there are a number of factors that determine mono-cities:

existence of one or more enterprises of one production process;

Deprivation of the population of the opportunity to choose a career;

distance of the settlement from the regional centers;

Dependence of the budget on the enterprise forming the city [1].

In addition to mono-specialized settlements, there are rural settlements with the status of specialized in the forest industry, as well as settlements whose functions are mainly railway transport and military service, recreational services, science-based cities and closed territorial structures.

Research on monotowns in foreign literature appeared much earlier. J. was one of the first in this field. Allen thought. He introduced the term "one company town" to science, focusing on cities that specialize in coal mining, oil and timber industries. The same term J. It was used in Garner's works in the analysis of New England's mono-cities. X. While analyzing these structures and their place in the U.S. economy, Green believes that they actually form the basis of the U.S. economy ${ }^{4}$. If we look at the division of mono-cities in the direction of the city-forming enterprise, we often see the following types of mono-cities:

* Coal mining (Angren, Shorgun) The problems of these areas include the peculiarities of coal mining, including heavy mining and

${ }^{4}$ Komilova, N.K., Ravshanov, A.K., Karshibaeva, L.K., Ishankulova, K.Q., \& Madrahimova, Z.N.(2020) Some theoretical and practical issues of medical geographical research. Indian Journal of Forensic Medicine and Toxicology. 14(3) 2086-2092. geological conditions, climatic conditions, persistent glaciers, great depths.

* Mechanical engineering monocities (including Asaka);

* Non-ferrous metallurgical mono-cities (Almalyk, Zarafshan, Uchkuduk, Muruntau, Gozgan, Ingichka, Marjanbulak, etc.);

* Chemical industry (town of chemists near Samarkand);

* Mono-cities of oil and gas industry. They are shift settlements registered as temporary settlements (Karavulbozor, Mubarek, Shargun, Lalmikor, Kakaydi, Polvontash, Gazli, etc.);

* "Science" cities In which the enterprises that make up a city are complexes that carry out scientific, scientific-technical, experimental or innovative activities;

* Information technology mono-cities (two scientific cities for information technology development were created in Russia: Innopolis and Skolkovo, and they were designed to serve as centers of innovation, information and communication technologies);

* Recreation and tourism cities Chartak, Yangiabad, Nanay, etc.

Another common concept abroad is - single industry townl, or -one industry town\| - single industrial city\| or -one industrial city\| (indicating its specialization). For example, - minig town\| - mining, wayrailway town\| railway transport, -college townll - educational services at a large university, - lumber towns\| timber production [6]. In foreign literature we can see a variety of terms that reflect the functional specialization of the city, as well as special attention is paid to the reflection of property rights in these terms.

It should be noted that this industry is a factor in the formation of the city and plays a special role in the socio-economic development of the region. Therefore, in the process of research, the aspects of the formation and development of mining cities were studied, their specific features were revealed, the definition of the concept of "mining cities" was developed. 
Based on modern methodologies and methods of interdisciplinary integration cooperation, it should be noted that "mining cities" are a complex urban structure, formed in the era of historical industrialization, based on the production of traditional mining and metallurgical industries, socio-cultural and architecturally unique. are urban settlements with a description of sustainable development. In particular, many cities in Navoi region are important centers of the mining industry in the country. ${ }^{5} 1950$ s, and this was influenced by its natural conditions. The level of industrialization and the transformation of settlements into cities played an important role in the formation of subsequent cities and population growth. Most of the "new" cities in the region were formed in the $60-80 \mathrm{~s}$ of the last century during the exploitation of various mineral resources.

\footnotetext{
${ }^{5}$ Murtazaev I.B. On the issue of developing a strategy for the socio-economic development of the Navoi region // Economy and entrepreneurship. No. 12. Moscow, 2017. -S. 324-326.
} 
$1^{\text {st }}$ table

The main indicators of development of mining cities of Navoi region

\begin{tabular}{|c|c|c|c|c|c|c|c|c|c|c|c|}
\hline \multirow[b]{2}{*}{$\begin{array}{l}\text { Names of } \\
\text { cities }\end{array}$} & \multirow[b]{2}{*}{$\begin{array}{c}\text { Year of } \\
\text { establish } \\
\text { ment }\end{array}$} & \multirow{2}{*}{$\begin{array}{c}\text { Year of } \\
\text { city } \\
\text { status }\end{array}$} & \multirow[b]{2}{*}{ Leading industry } & \multicolumn{8}{|c|}{ Population (thousands) } \\
\hline & & & & $1958 y$ & $1960 y$ & $1970 y$ & $1980 y$ & $1990 y$ & $2000 y$ & $2010 y$ & $2020 y$ \\
\hline Navai & 1957 & 1958 & $\begin{array}{l}\text { The city of Navoi is } \\
\text { characterized by territorial-urban } \\
\text { integration of industrial } \\
\text { enterprises (they belong to the } \\
\text { chemical, non-ferrous } \\
\text { metallurgy, construction } \\
\text { materials and electricity) }\end{array}$ & 5000 & $\begin{array}{l}10 \\
000\end{array}$ & 61,9 & 83,8 & 121,4 & 144,0 & 131,0 & 143,9 \\
\hline Zarafshan & 1972 & 1973 & $\begin{array}{l}\text { It specializes mainly in gold } \\
\text { mining, but also in the } \\
\text { processing of minerals such as } \\
\text { silver and marble. }\end{array}$ & - & - & 14,7 & 31,4 & 57,7 & 64,6 & 72,5 & 83,8 \\
\hline Uchquduq & 1958 & 1960 & $\begin{array}{l}\text { It specializes in the processing } \\
\text { of uranium ore and the } \\
\text { production of the raw material } \\
\text { needed for this enterprise, } \\
\text { namely sulfuric acid }\end{array}$ & - & 3,8 & 18,9 & 22,9 & 24,7 & 27,1 & 29,5 & 29,2 \\
\hline
\end{tabular}

The table was developed by the authors based on statistical data. 
According to available data, there was not a single city in the province until the late "Mining cities" are specific settlements, which can be proposed to connect them through a single chain of logic between the three components, namely, "city - mining - economy." As a result, the city appears to be "connected" to a particular area at a particular time. The most important component of this trio, an important force driving the socioeconomic development of the region, is the factor of mining.

\section{State interests as a macroeconomic factor}
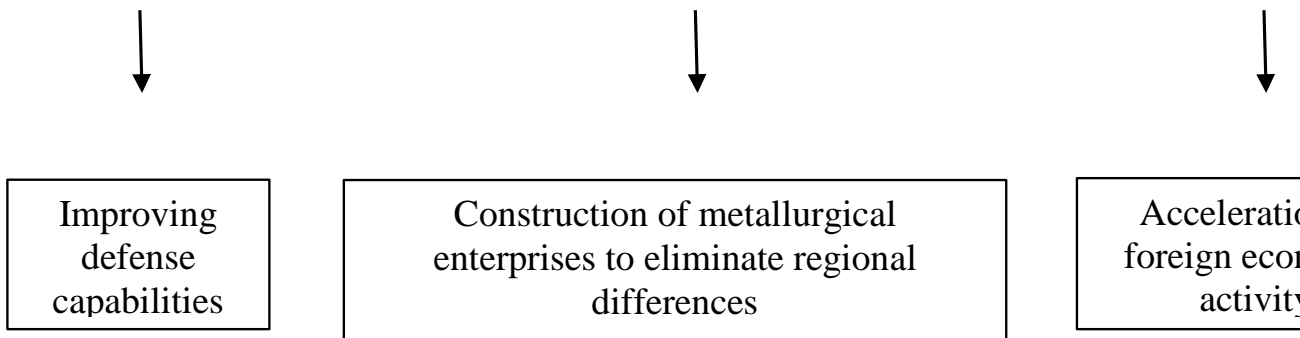

capabilities

$$
\text { differences }
$$

Acceleration of foreign economic activity

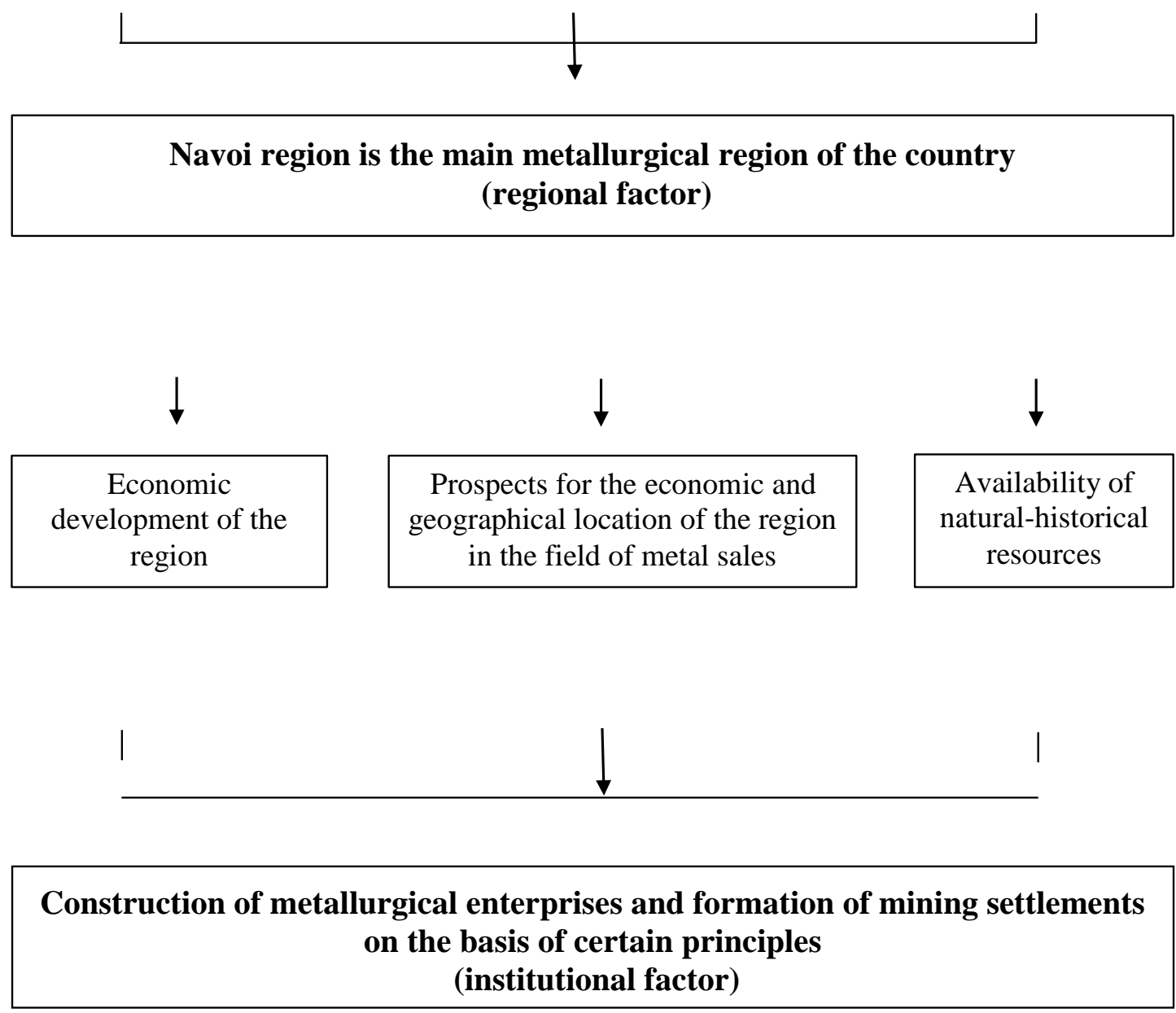

Figure 1. The main factors in the formation and development of mining cities

A comprehensive analysis of the mining towns of Navoi region, covering the period from 
their formation to the present, allowed to divide the history of their development into certain stages.

The first stage corresponds to the period of industrialization in Uzbekistan in the 50s of the XX century. The new wave of industry, which began in the 1960s, has boosted resource extraction, as well as the construction of new mono-cities in the engineering, oil and gas industries.

The rapid development of industry in mining cities has served to ensure high rates of population growth (Table 1).

Relationships in the "city-miningeconomy" chain have become more complex, and there have been significant changes, mainly in the "mining-production" component. More than 70 percent of the population engaged in social production accounted for the metallurgical industry. As a result, the level of dependence of the city on the main (city-forming) enterprise increases. The decline in urban diversification has led to a number of economic and social problems.

The third stage of development of mining cities begins in 1991, when our country gained political independence. In the first years of independence, Navoi region was registered as an independent administrative-territorial unit. Navoi Mining and Metallurgical Combine has played an important role in increasing the financial strength of the country. The production, processing and export volumes of gold, silver and other precious metals have grown significantly.

A thorough analysis of the content and essence of the concept of "mining cities" based on the integral relationship of the components "city mining - economy" allowed us to determine that the formation and development of mining cities in Navoi region takes place on the basis of certain laws.

As a result, the factors influencing this process were systematized during the research process. We believe that the macroeconomic factor should be highlighted in terms of the national interest. The need for the development of this sector is related to the need to increase the country's defense capabilities, accelerate foreign economic activity and eliminate regional disparities. $^{6}$

Conclusion. In general, the formation of cities is the result of political, social, economic and historical processes, the development of which is determined by the development of productive forces. The analysis shows that a comprehensive study of the formation, development and socioeconomic stability of single-industry towns, analysis of existing problems and the active implementation of a mechanism to support the development of single-industry towns in Uzbekistan, especially their mining cities, is one of the most pressing issues today. is calculated. This will require the adoption of appropriate regulations for the development of single-industry towns and the conduct of systematic research in this regard.

\section{References:}

[1] Komilova, N.Kh., Hudayberganova, R.T, Murtazaev, I.B., Abdinazarova, H.O., \& Madaminov, Z.H. (2019). Economic and Geographic Problems of Improvement of Industrial Sectors and Local Structure of Uzbekistan. Journal of Advanced Research in Law and Economics, 10 ( 6 (44)), 19161928.

[2] Komilova, N. K., Haydarova, Ş. A., Xalmirzaev, A. A., Kurbanov, S. B., \& Rajabov, F. T. (2019). Territorial Structure of Agriculture Development in Uzbekistan in Terms of Economical Geography. Journal of Advanced Research in Law and Economics, $10(8$ (46)), 2364-2372.

[3] Ismatov J.A. Monocities and features of their socio-economic development. Information of the Geographical Society of

\footnotetext{
${ }^{6}$ Murtazaev I.B. The question of development of the strategy for socio economic development of the Navoi region. European journal of economics and Management Sciences. №3. Vienna, 2018. -P. 36-40.
} 
Uzbekistan, T. University, 2018, №54. 84-88 b.

[4] Komilova, N.K., Ravshanov, A.K., Karshibaeva, L.K., Ishankulova, K.Q., \& Madrahimova, Z.N.(2020) Some theoretical and practical issues of medical geographical research. Indian Journal of Forensic Medicine and Toxicology. 14(3) 2086-2092.

[5] Murtazaev I.B. On the issue of developing a strategy for the socio-economic development of the Navoi region // Economy and entrepreneurship. No. 12. Moscow, 2017. -S. 324-326.

[6] Murtazaev I.B. The question of development of the strategy for socio economic development of the Navoi region. European journal of economics and Management Sciences. №3. Vienna, 2018. -P. 36-40.

[7] Turgel ID Monofunctional cities of Russia: from survival to sustainable development: monograph. - Moscow: Direct-Media, 2014 .-- 765 p. - ISBN 978-5-4458-43207. 